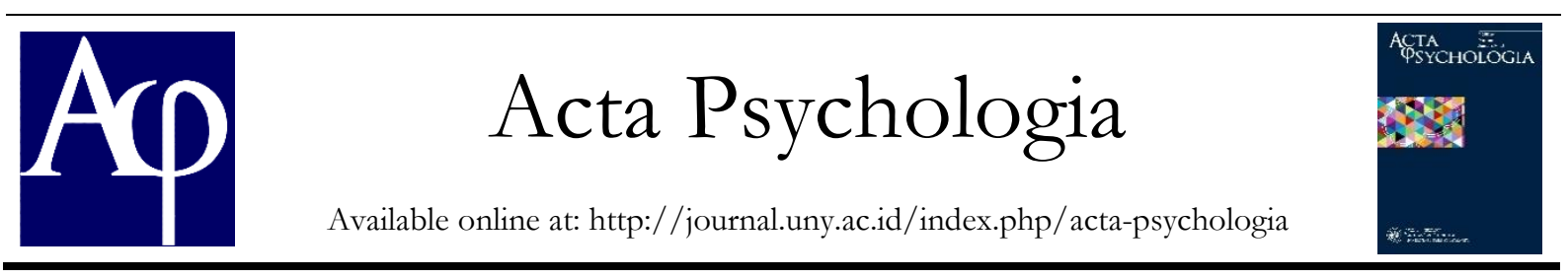

\title{
Perbedaan Organizational Citizenship Behavior Guru Sekolah ditinjau dari Jenis Kelamin
}

\author{
Rabma Wiranti Lestari \\ Jurusan Psikologi, Fakultas Ilmu Pendidikan, Universitas Negeri Yogyakarta; \\ J1. Colombo No. 1 Sleman Yogyakarta, 55281 \\ arinurastirahma@gmail.com
}

\begin{abstract}
Abstrak
Penelitian ini bertujuan untuk mengetahui perbedaan Organizational Citizenship Behavior (OCB) pada guru Sekolah Dasar yang ditinjau dari jenis kelamin. Penelitian ini dilakukan pada guru Sekolah Dasar Kecamatan Gedongtengen dengan populasi guru sejumlah 63 subjek. Pengumpulan data menggunakan skala Organizational Citizenship Behavior yang terdiri dari 5 aspek yaitu conscientiousness, sportsmanship, civic virtue, courtesy, dan altruism. Pengujian validitas dan reliabilitas skala OCB menggunakan uji ahli dan uji reliabilitas Alpha Cronbach sebesar 0,853. Sementara itu, untuk uji perbedaan digunakan independent samples t-Test. Hasil analisis data menunjukkan adanya perbedaan OCB pada guru laki-laki dan perempuan. Pada uji hipotesis yang dilakukan, diperoleh hasil $(\mathrm{t}=2,612 ; \mathrm{df}$ 57; $\mathrm{p}<0.005)$ hal itu menunjukkan bahwa terdapat perbedaan antara kelompok guru laki-laki dan perempuan. Berdasarkan hasil perhitungan, didapatkan hasil OCB guru laki-laki lebih tinggi dibandingkan guru perempuan.
\end{abstract}

Kata Kunci: organizational citizenship behavior, guru, jenis kelamin

\begin{abstract}
This study aims to determine the difference Organizational Citizenship Behavior (OCB) on elementary school teachers viewed by gender. This study was conducted on elementary school teachers in Gedongtengen district with a teacher population of 63 subjects. Data collection used Organizational Citizenship Behavior scale consisting of 5 aspects such as conscientiousness, sportsmanship, civic virtue, courtesy, and altruism. The validity and reliability testing of the OCB-scale used expert testing and the reliability test of Alpha Cronbach amounted to 0.853. Meanwhile, to test the difference is used independent samples t-Test. Data analysis results indicate OCB differences in male and female teachers. On the hypothesis test conducted, obtained results $(t=2.612 ; \mathrm{df} 57 ; \mathrm{p}<0.005)$ showing that there is a difference between a group of male and female teachers. Based on the calculation results, the results of the male teacher OCB are higher than the female teacher.
\end{abstract}

Keywords: organizational citizenship behavior, teachers, gender

\section{Pendahuluan}

Guru memiliki arti penting untuk keberhasilan pendidikan. Peran penting guru sebagai pengajar sekaligus pendidik merupakan faktor penentu keberhasilan pendidikan (Rida, Dantes, \& Dantes, 2013). Berdasarkan perilaku keorganisasian, tuntutan yang dihadapi guru sebagai seorang yang profesional memiliki beberapa keterbatasan. Keterbatasan tersebut dapat berupa keterbatasan yang dimiliki oleh guru itu sendiri ataupun keterbatasan mengenai tuntutan yang diharapkan dari profesi guru.

Menurut Katz (1964) terdapat tiga kategori perilaku kerja yaitu individu terikat dan ada di dalam organisasi, diwajibkan menyelesaikan peran khusus dalam pekerjaannya, dan mengharuskan terikat pada aktivitas yang inovatif dan spontan di luar perannya. Kategori terakhir itu yang dikatakan sebagai extra role atau organizational citizenship behavior. Organizational Citizenship 
Behavior (OCB) merupakan perilaku positif yang menguntungkan organisasi, namun bukan termasuk dalam tugas pokoknya (Duffy \& Lilly, 2013). Menurut Organ (1988) OCB dapat meningkatkan fungsi efektif organisasi, hal ini termasuk sekolah. Sekolah merupakan organisasi yang menaungi para guru diharapkan dapat berjalan dengan baik, Jafari dan Bidarian (2012) menganggap bahwa ada beberapa faktor yang melandasinya seperti perilaku organisasi, komitmen, tanggung jawab, sikap berani dan pekerja yang bijaksana. Faktor pekerja ini sama halnya dengan guru yang berada di sekolah. Dapat dikatakan bahwa faktor guru yang bijaksana merupakan salah satu faktor paling dasar dalam keberhasilan sekolah. Guru di sekolah dituntut tidak hanya melaksanakan tugasnya sebagai seorang guru, melainkan juga mampu beradaptasi dengan lingkungan sekolah. Salah satunya dengan rekan kerja. Guru diharapkan mampu berkoordinasi dengan baik, membantu rekan, ataupun menghindari perilaku yang merugikan sekolah.

Pada sektor pendidikan seperti sekolah, pekerja perempuan relatif lebih banyak jumlahnya dibanding pekerja laki-laki (Sari, Sampeadi dan Sunardi, 2018). Jenis kelamin dalam partisipasi angkatan kerja untuk lakilaki $80 \%$ sementara $50.2 \%$ untuk perempuan berdasarkan data yang dikeluarkan ILO (International Labour Organization) tahun 2014. Terkait dengan guru, guru laki-laki dan perempuan memiliki karakteristik psikologis dan fisik yang berbeda, terutama dalam melakukan pekerjaan (Sari, Sampeadi \& Sunardi, 2018). Hal tersebut yang memunculkan perilaku laki-laki dan perempuan berbeda dalam masyarakat maupun lingkup pekerjan. Lakilaki dan perempuan mempunyai tuntutan yang berbeda di masyarakat, termasuk guru di sekolah. Strereotipe masyarakat terhadap jenis kelamin juga berbeda-beda. Hal itulah yang membedakan jenis kelamin dalam sudut pandang peran di masyarakat (Ahdiah, 2013). Di sisi lain, dalam konteks organisasi atau pekerjaan baik laki-laki dan perempuan diharapkan dapat bekerja dengan baik bahkan memenuhi harapan lebih dari organisasi. Harapan lebih tersebut ialah Organizational Citizenship Behavior (OCB). Guru yang memiliki OCB yang tinggi akan sukarela melakukan hal-hal positif yang bersifat membangun sekolah. Guru yang memiliki OCB tinggi akan senang bekerja di sekolah dan merasa bahwa ia bagian dari sekolah. Sebaliknya jika OCB rendah, guru tidak terdorong dalam melakukan tugasnya, dan cenderung mengabaikan perkembangan sekolah.

Pada penelitian Beauregard (2000) perempuan diharapkan memiliki OCB yang lebih dan mendapatkan hukuman (punishment) jika tidak melakukannya. Piercy, Lane, dan Craves (dalam Dewi \& Perdhana, 2016) mengemukakan bahwa perempuan lebih terlibat banyak OCB dibanding lakilaki. Sementara itu laki-laki tidak diharapkan memiliki OCB tinggi dan mendapatkan apresiasi jika memiliki OCB yang tinggi. Perempuan seringkali memiliki OCB yang lebih tinggi dibanding laki-laki karena dianggap lebih rela membantu orang dan lebih murah hati (Farrel \& Finkelstein dalam Dewi \& Perdhana, 2016).

Belum banyak penelitian yang berfokus pada jenis kelamin dan pengaruhnya pada OCB menurut Punia dan Shyam (2017). Penelitian dari masalah OCB dan jenis kelamin ini didasarkan oleh pentingnya OCB terhadap organisasi. Setiap organisasi, dalam hal ini sekolah memiliki tujuan agar ada kontribusi yang dilakukan guru untuk menunjang keefektifan sekolah. Dalam penelitian yang telah dilakukan, ada hasil yang bertentangan antara pengaruh jenis kelamin dan OCB. Di lapangan juga ditemukan data yang berbeda dengan data empiris yang ada. Mengingat peran penting OCB yang bagi sekolah, maka tingkat OCB seharusnya baik agar membantu meningkatkan produktivitas dan efektivitas dari sekolah. Sehingga dapat diketahui tingkatan OCB pada guru laki-laki maupun 
perempuan sebagai salah satu dasar untuk menjadikan efektivitas sekolah lebih baik dari sebelumnya. Oleh karena itu pada peneliti melakukan penelitian untuk mengetahui perbedaan OCB pada guru SD ditinjau dari jenis kelamin.

\section{Metode Penelitian}

\section{Jenis penelitian}

Penelitian ini menggunakan pendekatan kuantitatif. Jenis penelitian ini termasuk dalam penelitian expost facto karena variabel yang digunakan tidak bisa dimanipulasi dan kejadian sudah sudah terjadi (Sugiyono, 2012)

\section{Waktu dan tempat penelitian}

Penelitian ini dilakukan mulai Januari- Mei 2019. Tempat penelitian dilakukan pada seluruh guru SD di Kecamatan Gedongtengen.

\section{Subjek penelitian}

Subjek dalam penelitian ini adalah guru sekolah dasar di Kecamatan Gedongtengen. Populasi guru Sekolah Dasar di Kecamatan Gedongtengen sejumlah 63. Adapun yang terlibat menjadi subjek penelitian yaitu 22 guru laki-laki dan 37 guru perempuan.

\section{Prosedur}

Prosedur pengumpulan data dalam penelitian ini menggunakan skala Organizational Citizenship Behavior (OCB). Subjek akan menilai pernyataanpernyataan yang sesuai dengan dirinya maupun tidak berdasarkan pilihan jawaban yang ada. Terdapat 23 pernyataan yang diberikan serta 4 pilihan jawaban berupa sangat setuju, setuju, kurang setuju, dan tidak setuju. Tidak ada jawaban benar atau salah dalam pengisian skala.

\section{Teknik pengumpulan data dan instrumen}

Dalam pengambilan data, instrumen yang digunakan merupakan skala OCB. Skala OCB ini digunakan untuk mengukur sikap, pendapat, maupun persepsi individu atau kelompok terhadap fenomena sosial (Sugiyono, 2012). Instrumen didasarkan pada Teori Organ 1988 yang berisi 5 dimensi yaitu conscientiousness, sportsmanship, civic virtue, courtesy, dan altruism. Kisi- kisi OCB dapat dilihat pada Tabel 1.

Tabel 1. Kisi-kisi skala Organizational Citizenship Behaviour

\begin{tabular}{|c|c|}
\hline Aspek & Indikator \\
\hline $\begin{array}{l}\text { Conscientiousness } \\
\text { (melakukan hal-hal } \\
\text { yang } \\
\text { menguntungkan } \\
\text { untuk sekolah) }\end{array}$ & $\begin{array}{l}\text { - Melaksanakan tugas lebih } \\
\text { dari harapan sekolah } \\
\text { - Menaati peraturan yang ada } \\
\text { di sekolah }\end{array}$ \\
\hline $\begin{array}{l}\text { Sportmanship } \\
\text { (toleransi pada } \\
\text { kekurangan yang } \\
\text { dimiliki sekolah } \\
\text { tanpa mengeluh) }\end{array}$ & $\begin{array}{l}\text { - Mampu memandang } \\
\text { sekolah sebagai tempat yang } \\
\text { nyaman untuk bekerja } \\
\text { - Menghindari hal-hal yang } \\
\text { menimbulkan pengaruh } \\
\text { negatif pada sekolah }\end{array}$ \\
\hline $\begin{array}{l}\text { Civic Virtue } \\
\text { (peduli terhadap } \\
\text { sekolah dengan } \\
\text { terlibat pada } \\
\text { kelangsungan } \\
\text { sekolah) }\end{array}$ & $\begin{array}{l}\text { - Melakukan hal-hal di luar } \\
\text { mengajar untuk mewakili } \\
\text { sekolah pada kegiatan } \\
\text { tertentu } \\
\text { - Memantau perkembangan } \\
\text { sekolah melalui media } \\
\text { informasi di sekolah }\end{array}$ \\
\hline $\begin{array}{l}\text { Courtesy } \\
\text { (menjaga hubungan } \\
\text { baik dengan sesama) }\end{array}$ & $\begin{array}{l}\text { - Mampu menghargai privasi } \\
\text { guru lain } \\
\text { - Tidak menggumbar } \\
\text { keburukan sesama guru }\end{array}$ \\
\hline $\begin{array}{l}\text { Altruism } \\
\text { (menolong rekan } \\
\text { kerja sesama guru) }\end{array}$ & $\begin{array}{l}\text { - Menolong rekan kerja dalam } \\
\text { penyelesaian pekerjaan } \\
\text { tanpa paksaan }\end{array}$ \\
\hline
\end{tabular}

\section{Teknik Analisis data}

Uji hipotesis penelitian dilakukan yaitu Independent sample t-test dengan bantuan program SPSS. Uji tersebut ditujukan untuk menguji perbedaan dua rata-rata kelompok yaitu OCB guru laki-laki dan OCB guru perempuan. Hipotesis di penelitian ini yaitu terdapat perbedaan OCB antara guru lakilaki dan guru perempuan di Sekolah Dasar yaitu OCB guru perempuan lebih tinggi dibanding guru laki-laki.

Dalam melakukan uji t-test terdapat uji prasyarat yang dipenuhi peneliti terlebih dahulu yaitu uji normalitas dan 
homogenitas. Menurut Siegel (1994) syarat dilakukan uji $t$ antara lain yaitu data independen, berdistribusi normal, memiliki varians yang sama atau homogen, dan variabel terukur setidaknya skala interval. Sudijono (2008) mengatakan bahwa terdapat perbandingan dua buah sampel pada uji t kecil, yaitu $n<30$ yang satu sama lain memiliki hubungan dan tidak. Sementara itu menurut Singgih (2004), t-test memiliki 3 syarat yaitu data berjenis interval atau rasio, jumlah sampel 2, dan hubungan antar sampel harus bebas. Pada dasarnya untuk mengetahui adanya perbedaan dengan uji $\mathrm{t}$ dapat dilakukan apabila data berdistribusi normal dan homogen (Yusri, 2013).

\section{Hasil Penelitian dan Pembahasan}

\section{Hasil Uji Deskriptif}

Pada Tabel 2 dapat dilihat bahwa rata-rata skor OCB pada guru laki-laki lebih tinggi daripada guru perempuan. Rata-rata skor OCB pada guru laki-laki $(\mathrm{n} 1=22)$ sebesar 80.727 adapun pada guru perempuan (n2=37) rata-rata skor OCB sebesar 76.189.

Tabel 2. Data deskriptif OCB

\begin{tabular}{lcc}
\hline & Laki-laki & Perempuan \\
\hline $\mathrm{n}$ & 22 & 37 \\
mean & 80.727 & 76.189 \\
minimum & 67 & 62 \\
maksimum & 88 & 89 \\
\hline
\end{tabular}

Skor OCB juga dikategorisan menjadi tiga kategori yaitu tinggi, rendah, dan sedang. Pada tabel 3 dapat dilihat bahwa sebagian besar guru laki-laki yaitu $63.6 \%$ memiliki OCB di kategori sedang, begitu pula guru perempuan yaitu $59.5 \%$.

Tabel 3. Data deskriptif OCB

\begin{tabular}{lcc}
\hline & Laki-laki & Perempuan \\
\hline Tinggi & $31.8 \%$ & $13.5 \%$ \\
Sedang & $63.6 \%$ & $59.5 \%$ \\
Rendah & $4.5 \%$ & $27 \%$ \\
\hline
\end{tabular}

\section{Hasil Uji Hipotesis}

Berdasarkan hasil uji normalitas diketahui bahwa nilai Kolmogorov-Smirnov pada data kelompok laki-laki sebesar 0.111 dengan $\mathrm{p}=0.200$. Adapun pada data pada kelompok perempuan sebesar 0.109 dengan $\mathrm{p}=0.200$. Dengan demikian kedua data berdistribusi normal. Kemudian hasil uji homogenitas dengan Levene test diperoleh signifikansi (p) sebesar 0.19 sehingga tidak ada perbedaan varian antar kelompok sehingga data homogen. Analisis kemudian dilakukan dengan uji independent sample t-test. Hasil uji independent sample t-test diperoleh perbedaan mean antara dua kelompok sebesar 4.538 dengan nilai $\mathrm{t}=2.612(\mathrm{df}=57)$ dan nilai signifikansi (p) $<.05$ sehingga terdapat perbedaan skor OCB yang signifikan antara guru laki-laki $($ mean $=80.727)$ dan perempuan (mean=76.189).

Tabel 4. Perbedaan mean tiap aspek dalam OCB

\begin{tabular}{lcc}
\hline \multicolumn{1}{c}{ Aspek } & Laki-laki & Perempuan \\
\hline Conscientiousness & 3.53 & 3.42 \\
Sportmanship & 3.64 & 3.37 \\
Civic Virtue & 3.44 & 3.21 \\
Courtesy & 3.46 & 3.23 \\
Altruism & 3.40 & 3.29 \\
\hline
\end{tabular}

Berdasarkan tabel 4, rata-rata nilai aspek pada laki-laki lebih tinggi dibandingkan perempuan. Meskipun demikian, pada aspek conscientiousness atau hal-hal yang dilakukan menguntungkan sekolah, perempuan dan laki-laki hanya berselisih sedikit yaitu 0.11 serta pada aspek altruism atau sikap untuk menolong sesama guru, perempuan hanya berselisih 0.11 di bawah laki-laki. Artinya, pada kedua aspek tersebut pada kelompok laki-laki maupun perempuan hampir sama atau cenderung seimbang. 


\section{Pembahasan}

Berdasarkan hasil uji independent sample t-test, hipotesis penelitian yang menyatakan terdapat perbedaan skor OCB pada guru laki-laki dan perempuan terbukti. Namun di penelitian ini skor OCB guru laki-laki ditemukan lebih tinggi dibanding guru perempuan. Tingkat organizational citizenship behavior pada laki-laki dan perempuan di kategori sedang. Namun, OCB pada lakilaki memiliki kecenderungan lebih tinggi dibandingkan dengan perempuan. Hal ini terlihat pada rata-rata hasil OCB yang menunjukkan bahwa nilai OCB kelompok laki-laki sebesar 80.73 sementara pada perempuan 76.19 .

Keseluruhan rata-rata OCB kelompok guru laki-laki dan perempuan memiliki selisih yang cukup jauh. Apabila dilihat dari aspek-aspek yang membentuk OCB, maka hanya terdapat perbedaan sedikit antara OCB laki-laki dan perempuan walaupun pada semua aspek laki-laki memiliki nilai yang lebih baik dibanding perempuan. Pada aspek conscientiousness dan altruism laki-laki memiliki rata-rata yang lebih baik sebesar 0.11. Selisih nilai tersebut dapat dikatakan kecil jika dibandingkan aspek lainnya. Artinya hanya terdapat perbedaan sedikit lebih baik laki-laki dibanding perempuan pada aspek tersebut.

Adanya kecenderungan perbedaan hasil yang lebih tinggi kelompok guru lakilaki dibandingkan dengan kelompok guru perempuan pada tingkat organizational citizenship behavior dimiliki berbeda dengan pernyataan Morrison (1994) yang menyatakan bahwa OCB perempuan lebih baik dibanding OCB laki-laki. Fokus pada penelitian ini yaitu OCB guru yang ditinjau dari jenis kelamin meskipun OCB laki-laki memiliki rata-rata yang lebih tinggi dibanding perempuan yang kemungkinan didapatkan karena beberapa faktor lain. Menurut Organ dalam Titisari (2014) OCB dipengaruhi oleh beberapa faktor seperti motivasi, moral guru, budaya organisasi dalam sekolah, kepribadian guru dan komitmen terhadap organisasi sekolah. Faktor lainnya yaitu masa kerja, usia, dan tingkat pendidikan. OCB tidak hanya dipengaruhi oleh satu faktor melainkan berbagai faktor, salah satunya jenis kelamin. Penelitian ini juga mendapatkan data dari usia dan masa kerja, meskipun demikian pengaruh kedua faktor tersebut kecil untuk menentukan tingkat OCB.

Kemungkinan yang paling besar sebagai alasan bahwa organizational citizenship behavior laki-laki lebih besar dari perempuan adalah karakteristik laki-laki dan perempuan serta kepribadian individu. Laki-laki cenderung diharapkan menjadi sosok yang bertanggung jawab dan menjadi pemimpin yang baik dalam lingkup pekerjaannya. Berbanding terbalik dengan perempuan yang masih dipandang lebih cocok dalam lingkup rumah tangga, bukan dunia kerja. Hal ini berdampak pada respon individu yang berbeda-beda, terutama laki-laki dan perempuan. Selain itu faktor internal dari individu seperti kepribadian individu. Baik laki-laki maupun perempuan memiliki kepribadian yang berbeda- beda dan cenderung menetap.

Berdasarkan kemungkinan yang telah dibahas sebelumnya, pada penelitian ini terdapat hal lain yang membuat OCB pada guru laki-laki lebih tinggi dibandingkan perempuan. Banyak faktor yang mempengaruhi $\mathrm{OCB}$, salah satunya adalah jenis kelamin. Artinya bahwa jenis kelamin bukan satu-satunya penentu tinggi rendahnya OCB seseorang. Berbagai faktor eksternal maupun internal lain seperti keadaan guru saat itu dan kepribadian yang dibentuk laki- laki dan perempuan tentu berbeda.

\section{Simpulan dan Saran}

\section{Simpulan}

Berdasarkan penelitian, terdapat perbedaan Organizational Citizenship Behavior (OCB) pada guru laki-laki dan perempuan di SD se- 
Kecamatan Gedongtengan. Guru laki-laki memiliki rata-rata skor OCB yang lebih tinggi dibanding guru perempuan.

\section{Saran}

Berdasarkan hasil penelitian yang telah dilakukan, terdapat saran bagi penelitian selanjutnya. Penelitian selanjutnya diharapkan dapat menggali lebih dalam faktor-faktor lain yang mempengaruhi OCB. Jenis kelamin dalam penelitian ini menunjukkan bahwa OCB laki-laki lebih tinggi dibanding perempuan, berbeda dengan penelitian-penelitian sebelumnya yang menyatakan bahwa perempuan diharapkan memiliki OCB yang lebih dibanding laki-laki.

\section{Daftar Pustaka}

Ahdiah, I. (2013). Peran-peran perempuan dalam masyarakat. Jurnal Academica , 5(2), 1085-1092.

Dewi, R.M. \& Perdhana, M.S. (2016). Peran gender, usia, dan tingkat pendidikan terhadap organizational citizenship behavior (OCB). 5, 1-9.

Duffy, J.A., \& Lilly, J. (2013). Do individual needs moderate the relationships between organizational citizenship behavior, organizational trust and perceived organizational support?. Journal of Behavioral and Applied Management, 14, 185.

Jafari, P., \& Bidarian, S. (2012). The relationship between organizational justice and organizational citizenship behavior. Procedia- Social and Behavioral Sciences, 47, 18151820.

Katz, D. (1964). The motivational basis of organizational behaviour. Behavioural Science, 9, 131-146.

Morrison, E.W. (1994). Role definitions and organizational citizenship behavior: The importance of the employee's perspective. Academy of Management Journal, 37, 1543-1567.

Organ, D.W. (1988). Organizational citizenship behavior: The good soldier syndrome. Lexington, MA: Lexington Books. Punia, A.P. \& Shyam,

Purnia, A.P., \& Shyam, R. (2017). Gender difference in of organisational behavior (OCB) and motives underlying OCB. Psychology and Behavioral Science International Journal,. 2, 1-5.

Rida, M., Dantes, N. \& Dantes, K.R. (2013). Hubungan motivasi kerja, masa kerja dan kesejahteraan guru terhadap profesionalisme guru sekolah dasar negeri di Gugus II Kecamatan Sukasada. E-journal Program Pascasarjana Universitas Pendidikan Ganesha, 3, 1-10.

Sari, R., Sampeadi, \& Sunardi. (2018). Perbedaan organizational citizenship behavior (OCB), kepuasan kerja dan stres kerja berdasarkan gender pada perawat instalasi rawat inap RSD Balung Kabupaten Jember. Bisma, 12, 31 340.

Siegel. S. (1994). Statistik non parametrik untuk ilmu- ilmu sosial. Jakarta: Gramedia

Sudijono, A. (2008). Pengantar statistik pendidikan. Jakarta: Raja Grafindo Persada.

Sugiyono. (2012). Metode penelitian kuantitatif kualitatif dan R๗B. Bandung: Alfabeta.

Titisari, P. (2014). Peranan organizational citizenship behavior (OCB) dalam meningkatkan kinerja karyawan. Jakarta : Mitra Wacana Media.

Yusri. (2013). Statistika sosial: aplikeasi dan interpretasi. Yogyakarta: Graha Ilmu 